九州大学学術情報リポジトリ

Kyushu University Institutional Repository

\title{
Utilization Analysis of Bioethanol (Low Grade) and Oxygenated Additive to COV and Gas Emissions on SI Engine
}

Abikusna, Setia

Automotive Engineering, Astra Manufacturing Polytechnic Jl.

Sugiarto, Bambang

Department of Mechanical Engineering, Universitas Indonesia

Yamin, Iqbal

Department of Mechanical Engineering, Universitas Indonesia

https://doi.org/10.5109/2740940

出版情報 : Evergreen. 7 (1)，pp.43-50，2020-03. 九州大学グリーンテクノロジー研究教育センター バージョン：

権利関係 : 


\title{
Utilization Analysis of Bioethanol (Low Grade) and Oxygenated Additive to COV and Gas Emissions on SI Engine
}

\author{
Setia Abikusna ${ }^{1, *}$, Bambang Sugiarto ${ }^{2}$, Iqbal Yamin ${ }^{2}$ \\ ${ }^{1}$ Automotive Engineering, Astra Manufacturing Polytechnic \\ Jl. Gaya Motor Raya No. 8 Sunter 2, Jakarta 14330 Indonesia \\ ${ }^{2}$ Department of Mechanical Engineering, Universitas Indonesia \\ Kampus Baru UI Depok, Depok 16424 Indonesia \\ E-mail: setia.abikusna@gmail.com
}

(Received October 31, 2019; Revised January 29, 2020; accepted February 24, 2020).

\begin{abstract}
The growth of motor vehicles over the past five years has reached $8.63 \%$ per year. The increasing number of vehicles has an impact on increasing fuel consumption. One alternative energy as another fuel currently being developed in motor vehicles is bioethanol. The addition of bioethanol will certainly change the fuel properties, the fuel will be more difficult to self-ignite so the pressure generated in the combustion chamber will be more consistent. The coefficient of variation $(\mathrm{COV})$ represents the ratio of the standard deviation to the mean of a set of data, in this study in-cylinder pressure data (IMEP) is used. Based on previous research that discussed the analysis of emission gas and fuel consumption on SI engine fueled with low-grade bioethanol and oxygenated additive, the authors examined further to analyze the characteristic of gasoline-ethanol blend and oxygenated additive to $\mathrm{COV}_{\text {IMEP }}$ and exhaust gas emissions of the various fuel mixture at variable engine speed were investigated. The results of the study show that gasoline-ethanol blend and oxygenated additive decrease variation in combustion pressure. It also reduces exhaust emissions; $\mathrm{CO}$ and $\mathrm{HC}$ are found to be reduced while $\mathrm{CO}_{2}$ and $\mathrm{O}_{2}$ increased as concentration increases.
\end{abstract}

Keywords: COV; emission; IMEP; oxygenated

\section{Introduction}

Research and development of spark-ignition engines are currently more focused on improving engine performance and reducing exhaust emissions. Those are important to find the substitution or at least additional fuel that can reduce the problems caused by the continuous fossil fuels used ${ }^{1,18}$. Bioethanol $\left(\mathrm{C}_{2} \mathrm{H}_{5} \mathrm{OH}\right)$ in future developments has the potential to become a renewable fuel. Bioethanol is a product of biomass-derived from the fermentation of plants containing starch. Bioethanol encompasses an easy molecular structure that easily defined chemical and physical properties. Bioethanol is often used as fuel either directly or as a combination of another fuel, like gasoline. Ethanol which can be used as an engine fuel is usually anhydrous ethanol with a concentration $>99.5 \%$ (fuel grade). If it is used entirely as fuel, engine modification is needed, but when mixed with gasoline, engine modification is not required ${ }^{2}$. Anhydrous ethanol used has very little water content and can even be said to be pure so that when mixed directly with gasoline, it can directly enter the combustion chamber. While hydrous ethanol which has low concentration and still has water content in it $(4.9 \%-5 \%)$ so it cannot be directly mixed with gasoline. To be used as a mixture with gasoline the maximum water content is $7.4 \%$. Therefore we need a simple technology that can accommodate low-grade ethanol produced by the community to be converted into high-grade ethanol, and the results can be directly applied as a mixture of fuel in the engine. Hydrous ethanol has slightly different characteristics compared to anhydrous ethanol ${ }^{3)}$. Octane is lower, heating value is lower, latent heat of vaporization is higher, then also the oxygen content is higher. However, the exact costs for each characteristic depend on the mixture content, and the water content contained, so a separate test of the hydrous ethanol is needed.

In addition to engine devoted to ethanol fuel, research into the use of ethanol is also carried out on commercial SI engine (gasoline engine) 4-cylinder, including testing the optimal level of mixtures on a mixture of gasoline-ethanol to maximize the efficiency of brake thermal. In this study engine performance like brake 
torque and brake specific fuel consumption were also tested with a combination ratio of gasoline (octane 87.5) and $99.5 \%$ ethanol (E10, E20, E30, E40, E50, E60, E70, $\mathrm{E} 85$, and E100). This test is carried out at different engine speed and throttle opening, but the ratio is constant. AFR and ignition timing are also adjusted to increase engine torque. From the results show that the proper mixing ratio of gasoline-ethanol can increase engine torque, especially at low engine speeds. E40 and E50 produce maximum thermal brake efficiency at $58-$ $73 \%$ WOT and a couple of 2,000 - 2,500 rpm. E20 - E40 produces the very best MBT at $70-100 \%$ WOT and $1,000-4,000 \mathrm{rpm}^{4}$. Comparative experiments have also been distributed on the port injection of gasoline engines with fuel hydrous ethanol gasoline (E10W), ethanol gasoline (E10) and pure gasoline (E0). In line with experimental results, compared to E0, E10W shows higher pressure within the cylinder and $\mathrm{NO}_{\mathrm{x}}$ emissions at high loads. However, at low loads the conditions of HC, $\mathrm{CO}$ and $\mathrm{CO}_{2}$ are significantly reduced. E10W also produces less $\mathrm{HC}$ and $\mathrm{CO}$, while $\mathrm{CO}_{2}$ emissions don't seem to be significantly affected. Compared to E10, E10W shows a better cylinder pressure and heat release rate. Also, a discount in $\mathrm{NO}_{\mathrm{x}}$ emissions was observed for $\mathrm{E} 10 \mathrm{~W}$ from $5 \mathrm{~nm}$ to $100 \mathrm{~nm}$, while $\mathrm{HC}, \mathrm{CO}$, and $\mathrm{CO}_{2}$ were slightly higher under low and medium load conditions. From the results, it will be concluded that the E10W fuel will be considered as a possible alternative fuel that may be applied to gasoline engines ${ }^{5}$.

Paper $^{6)}$ tests independently using low-quality distilled bioethanol which utilizes waste heat in a compact distillator to supply high-quality bioethanol able to be used as a fuel mixture. From the test, it had been found that the wheel torque and wheel power produced from a mix of gasoline and bioethanol have a better value than gasoline fuel only. The mix of bioethanol and gasoline will enhance power up to $15 \%$. Whereas the torque values produced within the mixture of E5, E10, and E15 are $6.92 \mathrm{Nm}, 6.64 \mathrm{Nm}$, and $6.92 \mathrm{Nm}$, respectively, where the worth is on top of pure gasoline at $6.1 \mathrm{Nm}$. Torque values were produced in an exceedingly mixture of E5, E10, and E15 with oxygenated additives respectively 7.5 $\mathrm{Nm}, 7.6 \mathrm{Nm}$, and $7.53 \mathrm{Nm}^{7)}$. The addition of oxygenated cyclohexanol, in general, can improve the performance (torque and power) produced by the fuel engine. Torque and brake power increase after engine rotation above $5,000 \mathrm{rpm}$. The highest torque value is obtained from the variation of $\mathrm{E} 10++$ at $9.09 \mathrm{Nm}$ at $6,000 \mathrm{rpm}$ engine speed, $2.6 \%$ higher than pure gasoline (E0). The most optimal power (brake power) is generated by a variable E15 of $6.84 \mathrm{~kW}$ at $8,000 \mathrm{rpm}$ engine speed which increases $1.94 \%$ from $\mathrm{E} 0^{8)}$.

Paper $^{9)}$ conducted an experiment to bring down variations of cyclic on test engines, by controlling timing of ignition for the full cycle in an exceedingly row. A stochastic model is performed between ignition timing and cylinder maximum pressure using system identification techniques. The utmost cylinder pressure from consequent cycle is estimated with this model. The control algorithm is generated from LabView and installed into the Field Programmable Gate Array (FPGA) chassis. The test results, the most cylinder pressure next cycle will be predicted quite well, and ignition timing will be adjusted to keep up the specified maximum cylinder pressure to reduce variations of cyclic. In fixed ignition timing trials, COV imep and COV Pmax were $0.677 \%$ and 3.764 , while the results decreased to $0.533 \%$ and 3.208 that after GMV controllers were applied.

S. H. Yoon, et. al., investigate characteristics of exhaust emissions, and engine performance of a spark-ignition engine fueled with bioethanol, ethanol-gasoline blend, and gasoline fuel ${ }^{10)}$. The test fuels were an ethanol-gasoline blend (E85), which consists of $85 \%$ vol bioethanol and $15 \%$ vol gasoline, pure bioethanol (E100), and gasoline fuel with none additive (G100). The results of this study showed that an ethanol-blended fuel or pure ethanol led to a drastic decrease in exhaust emissions under all operating conditions. The exhaust emissions like hydrocarbons, carbon monoxide, and nitrogen oxides were reduced when using the bioethanol-blended and undiluted ethanol fuel attributable to the highly oxygenated component of ethanol fuel.

Palmer, F.H. ${ }^{11)}$, reported that during low-speed acceleration, oxygenated fuel blend gave a better anti-knock performance than hydrocarbon fuel of similar octane range. Srinivasan, et. al. ${ }^{12)}$, experimented on the effect of the gasoline-ethanol mixture using oxygenated additives on the SI multi-cylinder Engine. The experiment shows that ethanol-gasoline blended with oxygenated additive indicates a significant reduction in exhaust emissions. $\mathrm{CO}, \mathrm{CO}_{2}$, and $\mathrm{NO}_{\mathrm{x}}$ were reduced, but in contrast to $\mathrm{HC}$ and $\mathrm{O}_{2}$ which are increasing.

In the previous research, the distillation of low-grade bioethanol with compact distillator was experimented ${ }^{6)}$ up to the analysis of emission gas and fuel consumption on the SI engine fueled with low-grade bioethanol and oxygenated additive was discussed ${ }^{13)}$. In this research, the authors checked further to analyze the characteristic of ethanol blend and oxygenated additive for $\mathrm{COV}_{\text {IMEP }}$ and exhaust gas emissions of various fuel mixture as well as $\mathrm{COV}_{\text {IMEP }}$ correlation with exhaust gas emissions at variable engine speed were investigated. The experimental study aims are to use a mixture of gasoline-engine and anhydrous ethanol with additive oxygenated which might reduce the COV of the combustion cycle so the engine driveability is increased as indicated by the resulting exhaust emissions.

\section{Coefficient of Variations (COV)}

$\mathrm{COV}$ combustion in SI engine is an important subject that has been widely studied because it limits the engine operating range. Many researchers have been done to 
observe the causes of cycle variations in the combustion process, leading to cycle variations in engine output performance. Cycle variations can be observed and characterized by the combustion pressure in the cylinder which is measured experimentally.

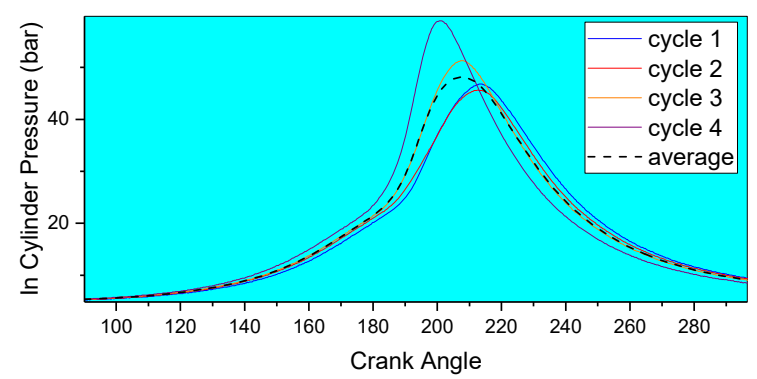

Fig. 1: Crank Angle vs Cylinder Pressure (uncertainty +0.15 )

Figure 1 shows a curve of cylinder pressure against the rotation of the crank angle in 4 consecutive cycles, it shows that maximum pressure for every cycle is different. The reason for this is that there is a possibility that the fuel in the cylinder does not burn at the same level. Using the statistical method coefficient of variations (COV) to represent the ratio of the standard deviation to the mean of a set of data, the combustion process of every cycle can be analyzed with a variety of in-cylinder pressure (IMEP) data experimented. Indicative Mean Effective Pressure (IMEP) and Pmax are important parameters and are commonly used as a measure of cyclic variation $^{14)}$. It should be noted that Pmax is additionally a feedback signal in an exceedingly closed-loop mechanism.

$$
C O V=\frac{\sigma_{I M E P}}{\mu I M E P} \times 100
$$

The standard deviation $(\sigma)$ is that the root of the common arithmetic of the square of the deviation from the mean $(\mu)$, and also the variance $(\sigma 2)$ is that the square of the quality deviation. The $\mathrm{COV}$ is defined as the ratio of the standard deviation to the mean value. To produce the effect of cyclic variation in combustion, work only given to piston during the compression and expansion steps, therefore $\mathrm{COV}$ is calculated as the standard deviation of the IMEP calculated between the closure of the intake valve and the opening of the exhaust valve, divided by average IMEP and is usually expressed in percent.

\section{Experimental Method}

In this study, we used a gasoline engine (SI) $125 \mathrm{cc}$ one cylinder with SOHC equipped and an electronic fuel injection system. Table 1 describes general gasoline engine specifications.
Table 1. Engine Test

\begin{tabular}{|l|l|}
\hline \multicolumn{1}{|c|}{ Specifications } & \multicolumn{1}{c|}{ Parameter } \\
\hline Kind of Gasoline Engine & SOHC, 4-stroke, one cylinder \\
\hline Displacement & $125 \mathrm{cc}$ \\
\hline Bore x stroke & $52.4 \mathrm{~mm}$ x $57.9 \mathrm{~mm}$ \\
\hline Ratio of Compression & About 9.3 vs 1 \\
\hline Power (max) & $7.4 \mathrm{~kW}$ at $8,000 \mathrm{rpm}$ (high speed) \\
\hline Torque (max) & $9.3 \mathrm{Nm} \mathrm{at} \mathrm{4,000} \mathrm{rpm} \mathrm{(medium}$ \\
speed) \\
\hline Fuel Mechanism & Injection (PGM-FI) \\
\hline Lubricant (max capacity) & 0.7 L (maintenance periodicaly) \\
\hline Kind of Clutch & Clutch type of multiple wet with \\
Coil/Volute Spring \\
\hline Kind of Transmission & Rotary and Manual (4 speed) \\
System & Kick Starter system (electrical) \\
\hline Kind of Starter System & \\
\hline
\end{tabular}

Fuel type used is pure gasoline (RON 88), gasoline-bioethanol mixture, with a mix of E5, E10, and E15, and therefore the mixture is added with oxygenated cyclohexanol additive $\left(\mathrm{C}_{6} \mathrm{H}_{12} \mathrm{O}\right)$, with a composition of $0.5 \%$ you bored with each mixture (E5++, E10++, E15++). Gasoline and bioethanol are mixed within the fuel tank. So, the premix level is kind of high and almost constant even to the manifold. Thus, the fuel flow may be controlled and measured directly. The fuel properties test of varied gasoline-bioethanol mixtures were also applied during this experiment. Table 2 describes the results of testing various fuels. 
Table 2. Fuel Properties Test

\begin{tabular}{lcccccc} 
Properties & & E0 & E5 & E10 & E15 & Method \\
\hline RON & & 87.9 & 90.5 & 93.6 & 96.5 & ASTM \\
& & & & & & D-2699 \\
\hline Oxygen & $\%$ & 0 & 2 & 4.1 & 5.9 & ASTM \\
& $\mathrm{m} / \mathrm{m}$ & & & & & D-4815 \\
\hline Pressure of Vapor & $\mathrm{kPa}$ & 48.6 & 38.8 & 68.7 & 65.8 & ASTM \\
& & & & & & D-323 \\
\hline Gravity & $\mathrm{Kg} / \mathrm{m}^{3}$ & 718 & 728 & 746 & 749 & ASTM \\
Specific at $15^{\circ} \mathrm{C}$ & & & & & & D-4052 \\
\hline
\end{tabular}

Kistler type 6617B, one piezoelectric sensor, for measure the combustion pressure on the cylinder (where the most combustion pressure until 200 bar) and therefore the acquisition system like LabView is employed to record the combustion pressure. The crank angle position (until 720 crank angle) is got by shaft encoder; the cylinder pressure is synchronized with the crankshaft angle. The temperature of the fuel, lubricants, spark plugs, and exhaust gas are measured with a temperature sensor unit within the style of a $\mathrm{K}$ type thermocouple. The engine test is additionally connected to the engine dyno to investigate engine power, engine torque, and consumption of fuel, while to live the content within the exhaust gas like Hydrocarbons (HC), Carbon Monoxide (CO), Carbon Dioxide $\left(\mathrm{CO}_{2}\right)$, and excess air $\left(\mathrm{O}_{2}\right)$ using QROTECH-401 (gas analyzer 4/5). Air-fuel ratio analysis is finished employing an oxygen sensor (lambda) within the end of the manifold. Figure 2 is an experimental arrangement chart on SI engine (125 cc) connected to other components.

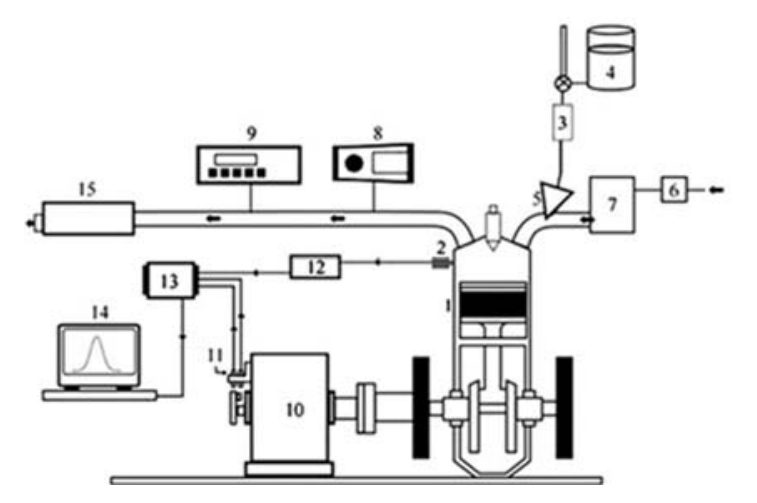

Fig. 2: Experimental Established SI Engine (1. Engine Test 2. Pressure Transducer 3. Gasoline Pump 4. Gasoline Tank 5. Injector 6. Air Filter 7. Air Stabilizing Tank 8. Smoke Meter 9.
Gas Analyzer 10. Eddy Current Dyno 11. CAD Encoder 12. Amplifier 13. DAQ 14. Monitor 15. Exhaust)

This experimental test is administrated after the engine operational until a steady-state condition. Temperatures of the cooling water and oil were at $50{ }^{\circ} \mathrm{C}$. The throttle opening angle is kept $100 \%$ open, also the timing of ignition is controlled by following the mechanism within the fuel injection system. Variations in engine speed are set at low speed $(4,000 \mathrm{rpm})$, medium speed, up to high speed $(8,500 \mathrm{rpm})$ with engine speed increases every $500 \mathrm{rpm}$.

\section{Result and Discussion}

\subsection{COV}

The characteristic of ethanol and oxygenated additive blend to $\mathrm{COV}_{\text {IMEP }}$ and exhaust gas emissions of various fuel mixture as well as $\mathrm{COV}_{\text {IMEP }}$ correlation with exhaust gas emissions at variable engine speed were investigated.

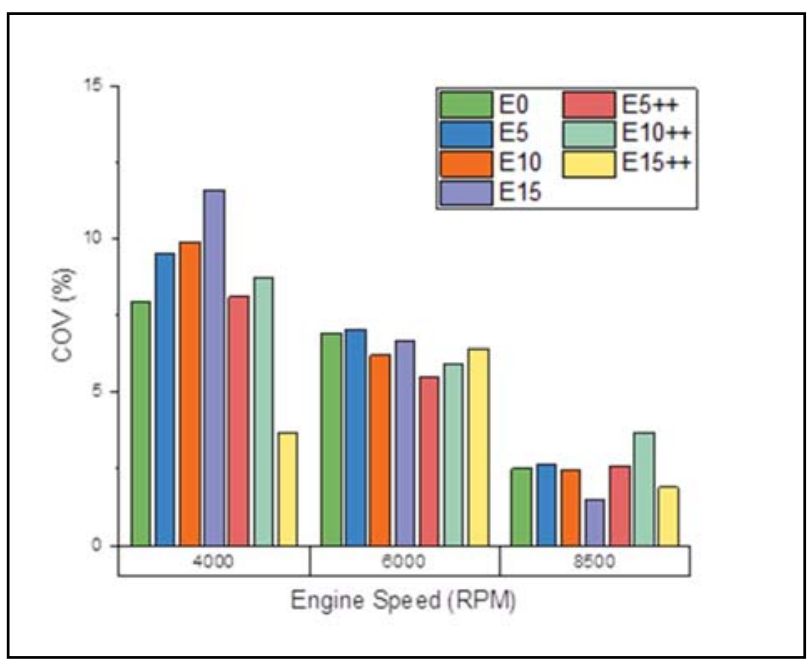

Fig. 3: COV vs. Engine Speed (uncertainty +0.15 )

$\mathrm{COV}_{\text {IMEP }}$ from an experimental test for every fuel mixture on engine speed 4,000, 6,000 and 8,500 RPM can be seen in Fig. 3. Figure 3 shows that additions of oxygenated additive on E15 fuel mixture can decrease $\mathrm{COV}$ in engine speed $4000 \mathrm{rpm}$ with value $3.67 \%$, decreased $4.27 \%$ compared to E0. And in engine speed $6,000 \mathrm{rpm}$, additions of oxygenated additive on E5 fuel mixture decreases COV $1.42 \%$ compared to E0. While in engine speed $8,500 \mathrm{rpm}$ on E15 fuel mixture, it decreases COV $1.01 \%$ compared to E0. Lower COV value indicates that the least variation in combustion pressure occurs.

Ethanol's affinity for water is high because it composed a certain amount of water in it. This is not a matter if you use entirely ethanol as fuel because it is mixed with water thoroughly, where ethanol has polar 
properties that are water-soluble, but some significant problems can arise when a mixture of gasoline-ethanol is used. Phase separation is very possible in this mixture because gasoline and ethanol cannot fully mix homogeneously. This problem can be avoided by using semi-polar solvents (improving solubility).

The Oxygenated additive added to each mixture of fuel from E5, E10, until E15 is cyclohexanol with a volume of $5 \%$ vol/vol. Cyclohexanol $\left(\mathrm{C}_{6} \mathrm{H}_{12} \mathrm{O}\right)$ including alcohol group, is a cyclic organic compound with carbon C-6 the presence of an $\mathrm{OH}$ group (alcohol). By increasing the length of the carbon chain, and with the presence of these groups, the influence of the polar hydroxyl group on the molecular nature tends to decrease. Therefore cyclohexanol is semi-polar. This becomes a binder between gasoline and ethanol so that the mixture can be more homogeneous.

\subsection{CO Emission}

The results of a mixture of the gasoline-ethanol with oxygenated additive to $\mathrm{CO}$ emissions are shown in Fig. 4. From the test results it can be obtained that the additions of oxygenated additive on gasoline-ethanol blend decrease CO emissions, especially in engine speed 4,000 rpm. Compared to the mixture without additive, additions of oxygenated additive to E5, E10, and E15 decrease $1.01 \%, 0.36 \%$, and $1.05 \%$ CO gas emissions respectively in engine speed 4,000 rpm. While in engine speed 6,000 rpm and 8,500 rpm it increases $0.99 \%$ and $2.15 \% \mathrm{CO}$ gas emissions of $\mathrm{E} 15$ fuel mixture respectively. This is because the percentage of ethanol and oxygen from oxygenated additive increases so it has resulted in leaner combustion. In general, for all concentration blend, as the concentration increase, the $\mathrm{CO}$ gas emissions are found to be reduced.

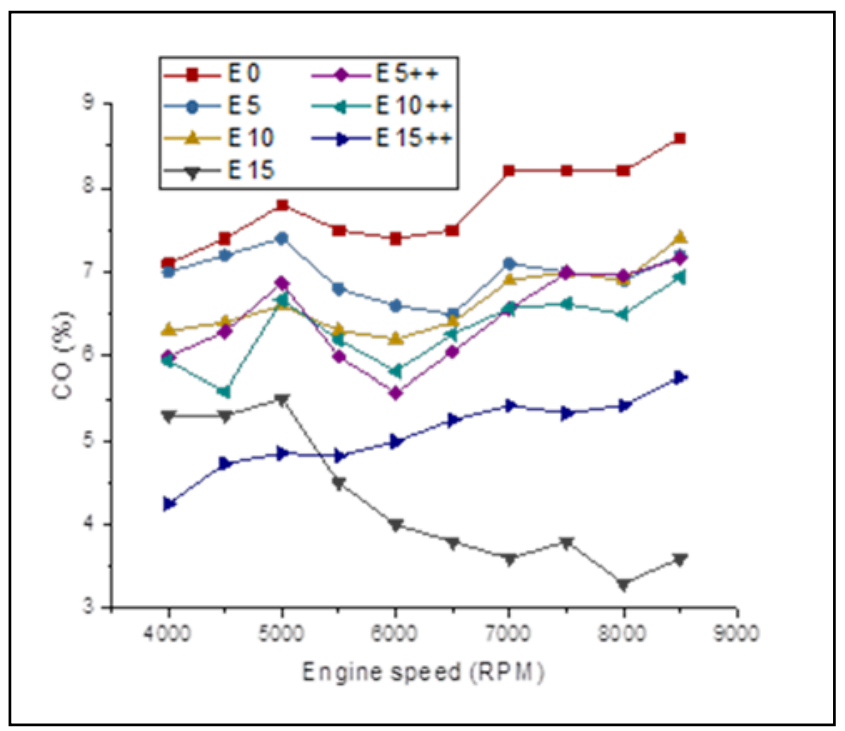

Fig. 4: CO vs. Engine Speed (uncertainty +0.197 )

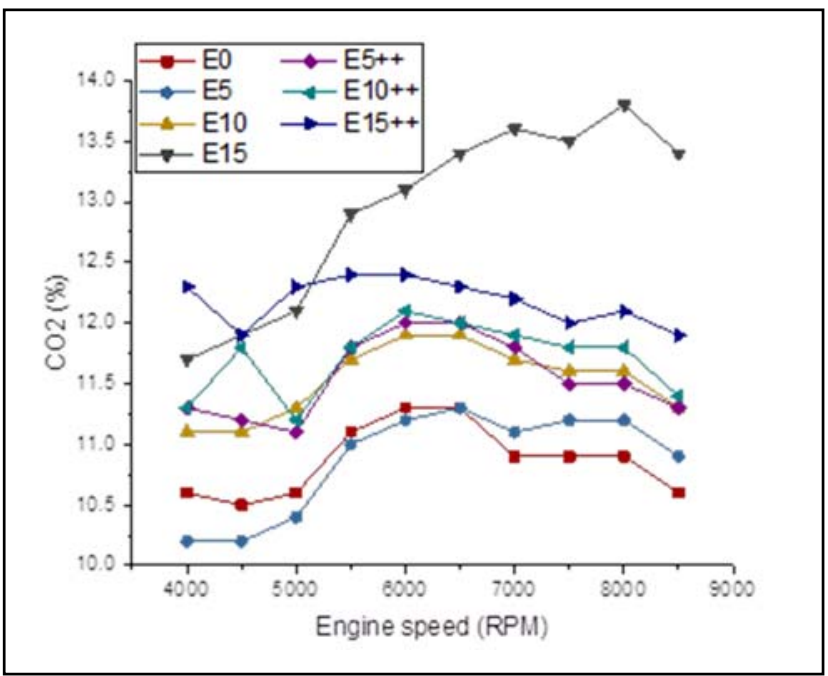

Fig. 5: $\mathrm{CO}_{2}$ vs. Engine Speed (uncertainty +1.292 )

The results of a mixture of the gasoline-ethanol with oxygenated additive to $\mathrm{CO}_{2}$ emissions is shown in Fig. 5 The additions of oxygenated additive on gasoline-ethanol blend increases $\mathrm{CO}_{2}$ emission, especially on lower engine speed. Compared to the mixture without additive, additions of oxygenated additive to E5, E10, and E15 increase $1.1 \%, 0.2 \%$, and $0.5 \%$ respectively in engine speed 4,000 rpm. While in engine speed 6,000 rpm and $8,500 \mathrm{rpm}$, it increases E5 and E10 $0.8 \% ; 0.2 \%$, and $1.4 \% ; 0.1 \%$ respectively. $\mathrm{CO}_{2}$ gas emissions increases due to the high oxygen content from the oxygenated additive, it indicates a better combustion process of the fuel in the combustion chamber.

\section{3 $\mathrm{O}_{2}$ Emission}

The results of a mixture of the gasoline-ethanol with oxygenated additive to $\mathrm{O}_{2}$ emissions is shown in Fig. 6 . The maximum oxygen content found in the exhaust gas was $1.6 \%$ at $4,000 \mathrm{rpm}$ with E15++ fuel mixture. As the concentration increases, $\mathrm{O}_{2}$ generally increased compared to pure gasoline. This is due to the high oxygen content contained by the oxygenated additive. Higher $\mathrm{O}_{2}$ emissions indicate that there is enough oxygen in the combustion process and fuel that is not burning, $\mathrm{HC}$ will be less rather than the lack of air and $\mathrm{HC}$ which will increase later. 


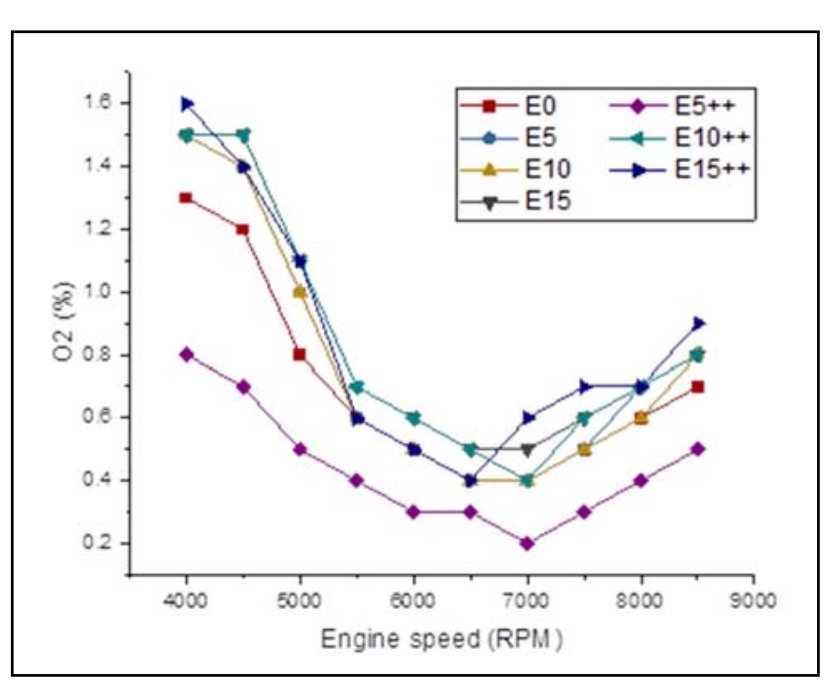

Fig. 6: $\mathrm{O}_{2}$ vs. Engine Speed (uncertainty +0.173 )

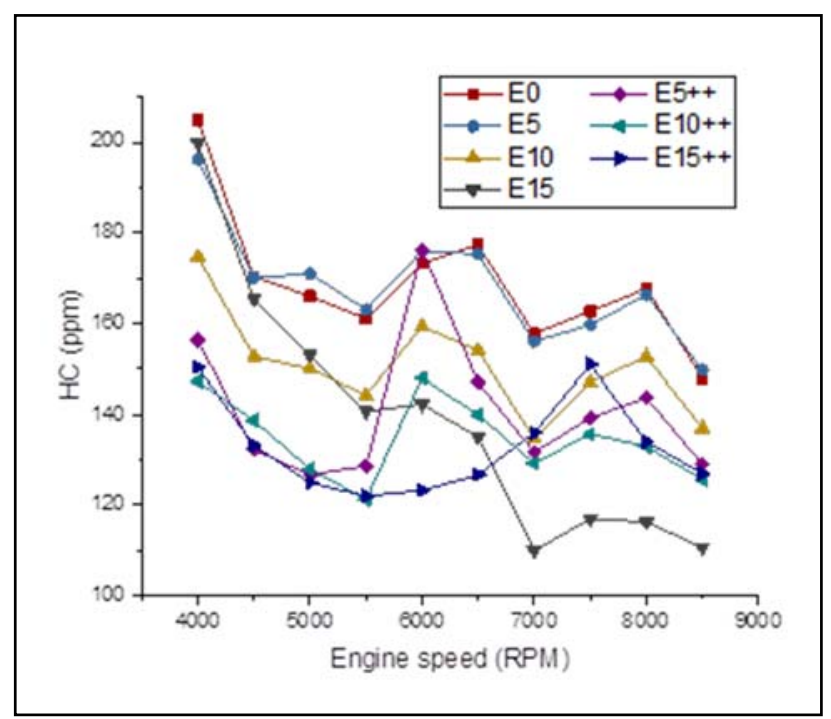

Fig. 7: HC vs. Engine Speed (uncertainty +12.737$)$

\subsection{HC Emission}

The results of a mixture of the gasoline-ethanol with oxygenated additive to $\mathrm{HC}$ emissions is shown in Fig. 7. From the test results it can be obtained that the additions of oxygenated additive on gasoline additive blend decrease HC, especially on lower engine speed. Compared to the mixture without additive, additions of oxygenated additive to E5, E10 and E15 decreases 40 ppm, 27.4 ppm and 49.4 ppm $\mathrm{HC}$ emissions respectively in engine speed 4,000 rpm. While in engine speed 6,000 rpm it decreases E10 and E15 HC emissions 8.7 ppm and $20 \mathrm{ppm}$ respectively. And in engine speed 8,500 rpm it decreases E5 and E10 HC emissions 20.7 ppm and 12.3 ppm respectively. Decreasing $\mathrm{HC}$ levels indicates a better combustion process. This is because $\mathrm{HC}$ compounds react with oxygen from ethanol and produce carbon dioxide $\left(\mathrm{CO}_{2}\right)$ and water $\left(\mathrm{H}_{2} \mathrm{O}\right)$.

\subsection{COV vs. Emission}

The correlations between $\mathrm{COV}$ and exhaust gas emissions such as $\mathrm{CO}, \mathrm{CO}_{2}, \mathrm{O}_{2}$, and $\mathrm{HC}$ can be seen in Fig. 8. From the graph obtained that at $6,000 \mathrm{rpm}$ compared to E0, $15 \%$ ethanol blend decreases COV value by $0.26 \%$. But with a non-significant decrease, it was able to reduce $\mathrm{CO}$ gas emissions by $3 \%$ and $\mathrm{HC} 31$ ppm and increase $\mathrm{CO}_{2}$ emissions by $1.8 \%$. And in 8,500 rpm engine speed it can be seen that $1.01 \%$ decrease of $\mathrm{COV}$ from $\mathrm{E} 0$ to $\mathrm{E} 15$ can reduce $\mathrm{CO}$ gas emissions by $5 \%$, $\mathrm{HC} 31 \mathrm{ppm}$ and increase $2.8 \% \mathrm{CO}_{2}$ gas emissions. While at 4,000 rpm engine speed, COV increases with every addition of $5 \%$ ethanol into the fuel and this still has an impact on reducing $\mathrm{HC}$ gas emissions, but not significantly only $5.3 \mathrm{ppm}$. This decrease is due to the properties of ethanol which contains a lot of oxygen so that $\mathrm{CO}$ and $\mathrm{HC}$ gas emissions slightly reduced and $\mathrm{O}_{2}$ and $\mathrm{CO}_{2}$ gas emissions still increase slightly even though the combustion process is not consistent.

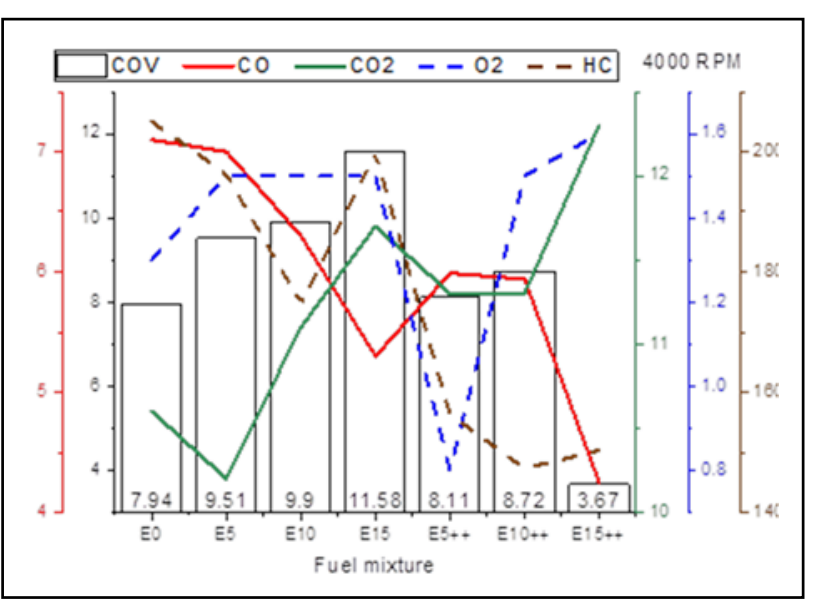

(a)

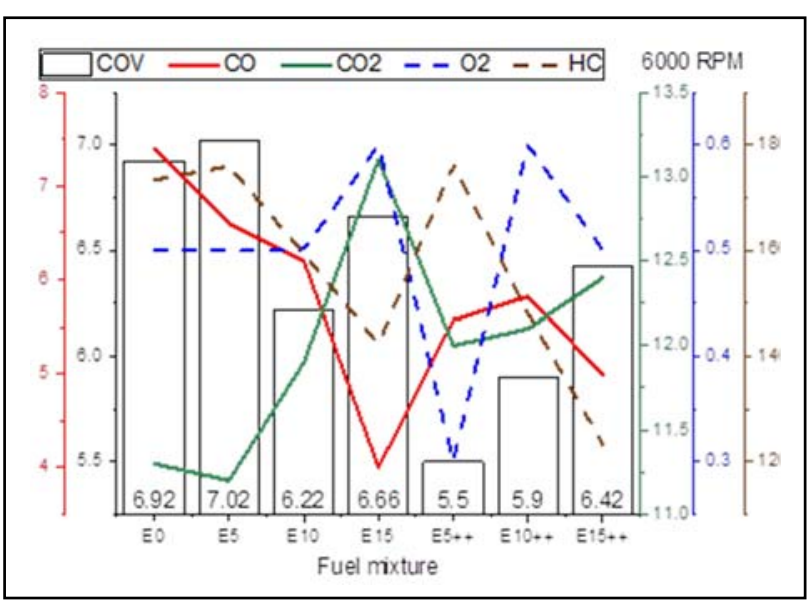

(b) 


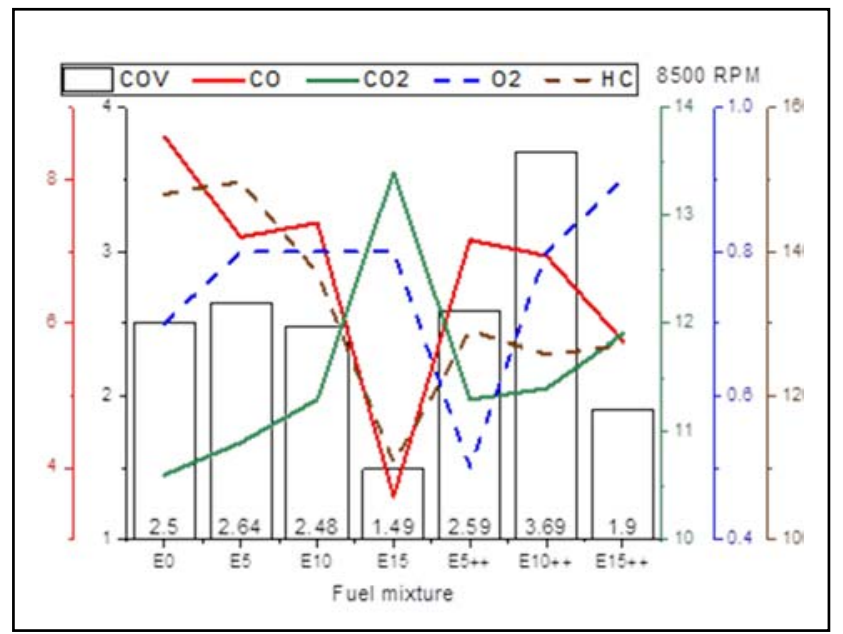

(c)

Fig. 8: Engine Speed 4,000 rpm (a), 6,000 rpm (b) and 8,500 $\operatorname{rpm}(\mathrm{c})$

Compared to the mixture without additive, generally, additions of oxygenated additive to E5, E10, and E15 decrease COV, especially in 4,000 rpm and 6,000 rpm engine speed. At 4,000 rpm fuel mixture E5, E10 and E15 with additive compared to those without it decreases COV value $1.4 \%, 1.18 \%$, and $7.91 \%$ respectively. And in 6,000 rpm it decreases COV value $1.5 \%, 0.32 \%$ and $0.24 \%$ respectively to E5, E10 and E15. While in 8,500 rpm it decreases $\mathrm{COV}$ value $0.05 \%$ for $\mathrm{E} 5$, it also increases COV value $1.21 \%$ and $0.51 \%$ to $\mathrm{E} 10$ and $\mathrm{E} 15$ respectively. As $\mathrm{COV}$ decreases, $\mathrm{CO}$ and $\mathrm{HC}$ emissions decreased while $\mathrm{CO}_{2}$ and $\mathrm{O}_{2}$ increased. on the contrary, while $\mathrm{COV}$ increased, $\mathrm{CO}$ and $\mathrm{HC}$ gas emissions slightly reduced and $\mathrm{O}_{2}$ and $\mathrm{CO}_{2}$ gas emissions still increase slightly even though the combustion process is not consistent. This is due to the high oxygen content of ethanol and oxygenated additive.

\section{Conclusion}

The following conclusions can be made from this study, ethanol blend and oxygenated additive in gasoline decrease variation in combustion pressure occurrences, lower COV. It also reduces exhaust emissions; $\mathrm{CO}$ gas emissions and $\mathrm{HC}$ emissions are found to be reduced while $\mathrm{CO}_{2}$ gas emissions and $\mathrm{O}_{2}$ gas emissions increased as concentration increases. The correlations between $\mathrm{COV}$ and exhaust gas emissions are; as $\mathrm{COV}$ decreases, $\mathrm{CO}$ and $\mathrm{HC}$ emissions decreased while $\mathrm{CO}_{2}$ and $\mathrm{O}_{2}$ increased. And when $\mathrm{COV}$ increased, $\mathrm{CO}$ and $\mathrm{HC}$ gas emissions slightly reduced while $\mathrm{O}_{2}$ and $\mathrm{CO}_{2}$ gas emissions still increase slightly even though the combustion process is not consistent. This is due to the high oxygen content of ethanol and oxygenated additive.

\section{Acknowledgement}

The authors would love to thank Kemenristekdikti RI for providing the grant PDUPT 2019 No.
NKB-1629/UN2.R3.1/HKP.05.00/2019 during this research, in order that it is completed well.

\section{References}

1) Ministry of Energy and Mineral Resources, Data Handbook of Energy \& Economic Statistic of Indonesia, 2014.

2) Alexios Kyriakides, Vasilis Dimas, and Eleni Lymperopoulou, Evaluation of Gasoline-EthanolWater Ternary Mixtures Used as a Fuel for an Otto engine. Fuel, 2013. 108: p. 208-215.

3) Sathaporn Chuepeng, Sudecha Srisuwan, and Manida Tongroon, Lean Hydrous and Anhydrous Bioethanol Combustion in Spark Ignition Engine at Idle. Energy Conversion and Management, 2016. 128: p. 1-11.

4) Balat M., and H. Balat, Recent Trends in Global Production and Utilization of Bio-Ethanol Fuel. Applied energy, 2009. 86(11): p. 2273-2282.

5) Masum B., Masjuki H., Kalam, and M. Fattah I., Effect of Ethanol-Gasoline Blend on NOx Emission in SI Engine. Renewable and Sustainable Energy Reviews, 2013. 24: p. 209-222.

6) Abikusna, Setia, Bambang Sugiarto, Dedi Suntoro, and Azami, Low Grade Bioethanol For Fuel Mixing on Gasoline Engine Using Distillation Process. AIP Conference Proceedings, 2017. 1826, 20019/doi.org/10.1063/1.4979235.

7). Abikusna, Setia, Bambang Sugiarto, and Ratna Monasari, Performance Analysis (WHP and Torque) on SI Engine Fueled with Low Grade Bioethanol and Oxygenated Fuel Additive. IOP Conference Series: Earth and Environmental Science, 2018. 105, 012057/doi.org/10.1088/1755-1315/105/1/012057.

8) Abikusna, Setia, Bambang Sugiarto, Ratna Monasari, and Iqbal Yamin, The Effect of Additive on Combustion Characteristics and Cycle to Cycle Variations on SI Engine Fueled by Gasoline and Bioethanol. Eastern European Journal of Enterprise Technologies, 2018. 6/6 (96).

9) Kaleli, A., M.A. Ceviz, and K. Erenturk, Controlling Spark Timing for Consecutive Cycles to Reduce the Cyclic Variations of SI Engines. Applied Thermal Engineering, 2015. 87: p. 624-632.

10) Yoon, S.H., S.Y. Ha, and H.G. Roh, Effect of Bioethanol as an Alternative Fuel on The Emissions Reduction Characteristics and Combustion Stability in a Spark Ignition Engine. 2009. 223(7): p. 941-951.

11) Palmer, F., Vehicle Performance of Gasoline Containing Oxygenates. in International Conference on Petroleum Based Fuels and Automotive Applications. IMECHE Conference Publications 1986-11. Paper No C319/86.

12) Srinivasan C. A. and C. Saravanan, Study of Combustion Characteristics of an SI Engine Fuelled with Ethanol and Oxygenated Fuel Additives. 
Journal of Sustainable Energy \& Environment, 2010. 1(2): p. 85-91.

13) Monasari, R., Bambang Sugiarto, and Setia Abikusna, Analysis of Emission Gas and Fuel Consumption on SI Engine Fueled with Low-Grade Bioethanol and Oxygenated Cycloheptanol Additive. IOP Conference Series: Earth and Environmental Science, 2018. 105, /doi.org/10.1088/1755-1315/ 105/1/012058.

14) Heywood, John B., Internal Combustion Engine Fundamentals. McGraw-Hill Series in Mechanical Engineering, 1988. ISBN 0-07-028637-X.

15) Wang X., Chen Z., Ni J., Liu S., and Zhou H.,The Effects of Hydrous Ethanol Gasoline on Combustion and Emission Characteristics of a Port Injection Gasoline Engine. Case Studies in Thermal Engineering, 2015. Vol. 6. P. 147-154.

16) Pamitran Agus Sunjarianto, Budiyanto Muhammad Arif, Maynardi R. Dandy Yusuf, Analysis of ISO-Tank Wall Physical Exergy Characteristic: Case Study of LNG Boil-off Rate from Retrofitted Dual Fuel Engine Conversion. Evergreen, 2019. 6(2), pp. 134-142.

17) Paryanto Imam, Prakoso Tirto, Susanto Heru Bambang, Gozan Misri, The Effect of Outdoor Temperature Conditions and Monoglyceride Content on the Precipitate Formation of Biodiesel-Petrodiesel Blended Fuel (BXX). Evergreen, 2019. 6(1), pp. 59-64.

18) Furutani Yuki, Norinaga Koyo, Kudo Shinji, Hayashi Jun-ichiro, Current Situation and Future Scope of Biomass Gasification in Japan. Evergreen, 2017. 4(4), pp. 24-29.

19) Dhilip Khatiwada, Scenarios for Bioethanol Production in Indonesia: How can We Meet Mandatory Blending Targets ? Energy, 2017. 119: p. 351-361.

20) Vinícius Rückert Rosoa, Effects of Mixture Enleanment in Combustion and Emission Parameters Using a Flex-Fuel Engine with Ethanol and Gasoline. Applied Thermal Engineering, 2019. 153: p. 463-472.

21) Policarpo, N.A., Emission Estimates for an On-Road Flex-Fuel Vehicles Operated by Ethanol-Gasoline Blends in an Urban Region, Brazil. Elsevier Urban Climate, 2018. 24: p. 111-120.

22) Phuangwongtrakul, S., Experimental Study on Sparking Ignition Engine Performance for Optimal Mixing Ratio of Ethanol-Gasoline Blended Fuels. Applied Thermal Engineering, 2016. 100: p. 869-879.

23) Sen, A. K., A. Medina, P. L. Curto-Risso, A. Calvo Herna'ndez, Effect of Ethanol Addition on Cyclic Variability in a Simulated Spark Ignition Gasoline Engine. Springer Science \& Business, Meccanica, 2014. 49:2285-2297.

24) Charles E. Wyman, Handbook on Bioethanol:
Production and Utilization. Applied Energy Technology Series, 2010.

25) Junfeng Yang, Cyclic Variation of Combustion in SI Engines. UnICEG Meeting University of Birmingham, 2018.

26) Zlata Mujikova, Water Tolerance of Petrol-Ethanol Blends. Preliminary communication University of Chemistry and Technology, Prague, 2016. 